\title{
Genotype $\times$ Environment Interaction and Phenotypic Stability analysis of Linseed (Linum usitatissimum L.) in Mid-Hills of North-West Himalayas
}

\section{Devender Sharma* and Satish Paul}

Department of Crop Improvement, College of Agriculture, CSK Himachal Pradesh Krishi Vishvavidyalaya, Palampur-176062 (H. P.), INDIA

*Corresponding author. E-mail: devenderyspuhf@gmail.com

Received: February 4, 2016; Revised received: August 7, 2016; Accepted: November 6, 2016

Abstract: Stability performance of 30 linseed genotypes including commercial cultivars and elite lines (indigenous and exotic) was compared by using regression on environmental means for grain yield and its components under 5 different environments during rabi 2013-2014. Significant differences were observed among the genotypes for all the traits studied over all 5 individual environments. Genotype $\times$ environment interactions were highly significant for all the characters studied. $E+(G \times E)$ was significant for all the characters except the number of seeds per capsule. Mean sum of squares for environment (linear) showed significance for all the characters. Significant differences for $\mathrm{G} \times \mathrm{E}$ (linear) were observed for 5 traits viz., primary branches per plant, secondary branches per plant, aerial biomass yield per plant, seed yield per plant and 1000-seed weight. Based on mean performance, regression coefficient (bi) and deviation from regression $\left(\mathrm{S}^{2} \mathrm{di}\right)$ the genotype Him Alsi-2, KL-241 and Nagarkot was highly stable for seed yield $(\mathrm{g})$ and number of capsules per plant was found most adaptive to overall environments. These promising genotypes may be utilized as donors in linseed improvement program for target ecosystems.

Keywords: $\mathrm{G} \times \mathrm{E}$ interaction, Linum usitatissimum, Selection, Stability, Varieties

\section{INTRODUCTION}

Linseed (Linum usitatissimum L.) commonly known as Alsi, is a multipurpose rabi oilseed crop, cultivated for oil and fibre, which belongs to the family Linaceae having 14 genera. It has somatic chromosome number $2 n=30$. Despite huge benefits of linseed, it is grown only in 24.86 lakh ha of area in the world with annual production and productivity of 20.55 lakh tonnes and $827 \mathrm{~kg} / \mathrm{ha}$, respectively. While, in India linseed production being 1.49 lakh tonnes from 2.96 lakh ha area with productivity of $502 \mathrm{~kg} / \mathrm{ha}$. India ranks second in terms of area after Canada, but third in terms of production after Canada and China, contributing about 14.89 per cent to world acreage and about 6.56 per cent to world production. The area under linseed cultivation in Himachal Pradesh is 1.17 thousand ha and production is 320 tonnes with an average yield of $270.0 \mathrm{~kg} / \mathrm{ha}$ (Anonymous, 2014).

Linseed (Linum usitatissimum L.) is an important oil seed crop in India. Every part of the plant is utilized commercially either directly or after processing. Linseed contains about $35-45 \%$ oil which is high in unsaturated fatty acids, especially linolenic acid (Khan et al., 2010) and 20-25\% protein (Gill, 1987; Fernald, 1950; Arora et al., 2003). The oil primarily goes to industries for the manufacturing of paints, varnish, oilcloth, linoleum, pad-ink and printing-ink. Oilcake is a good feed for milch cattle. Fibre obtained from stem is known for its strength, durability and even superior to cotton, rayon or wool. It is used to produce strong yarns such as sewing threads, linen fabrics, linen threads and the coarser grades are used for the manufacturing of rough textile like blankets, carpets, cushion covers, hand towel etc (Gill, 1987). Breeding cultivars that adapted reasonably larger geographical area with varying degree of stability from year to year has been a major problem confronting plant breeders. The only effective control might be to reduce environments by grouping them on the basis of their similar responses and subsequently evaluating genotypes in representative environments from each group (Compbell and Lafever, 1977). Moreover, yield levels are also not sustainable and fluctuate year after year. This fluctuation is because of many factors like growing of this crop on marginal lands, non-availability of resistant/ tolerant varieties for biotic and abiotic stresses for different ecological conditions. Under such a situation, it becomes, imperative to identify some already released varieties which can show a steady performance under different agro climatic conditions i.e. growing in different environments with respect to time and place. Keeping, this in view, the present investigation was carried out in 5 varying environments and 30 genotypes were studied to test the stability of the improved varieties over the environments through genotype $x$ environment interaction and to identify high yielding and stable varieties for stable production in linseed. 


\section{MATERIALS AND METHODS}

Experimental site: The experiments were conducted at 5 different locations under varying agroclimatic conditions viz., Palampur (two different sowings i.e $7^{\text {th }}$ October, 2013, $\mathrm{E}_{1}$; and $19^{\text {th }}$ November, 2013, $\mathrm{E}_{2}$ ), Malan $\left(E_{3}\right)$, Kangra $\left(E_{4}\right)$ and Dhaulakuan $\left(E_{5}\right)$ in Himachal Pradesh during rabi 2013-14. The material used for present study consisted of 30 varieties of linseed, (Table 1) which were evaluated for their stability under varying environmental conditions. The experiment was laid out in randomized block design with 3 replications having plot size of $1 \mathrm{~m} \times 0.75 \mathrm{~m}$. Row to row and plant to plant distance was kept at $25 \mathrm{~cm} \times 10 \mathrm{~cm}$.

Recording of observation: The data were recorded for 12 characters to evaluate the stability of genotypes (Table 2). For days to 50 per cent flowering and days to maturity data was recorded on plot basis while, the data for rest of the morphological traits were recorded on randomly selected 5 competitive plants in the middle 3 rows of each plot in all 3 replications. The recommended package of practices was followed to raise a good crop. The mean values of 5 sampled plants for all characters, except for characters days to 50 per cent flowering and days to maturity for which data recorded on whole plot basis, were used for detailed statistical analysis. Harvest index in percent was calculated by dividing the grain yield per plant in grams by the biological yield per plant in grams.

Methodology for oil extraction: Biochemical analysis was done using NMR for oil content analysis. The NMR method is indirect, non-destructive, which helps in the rapid analysis of oil content of linseed cultivars in a breeding program The NMR technique measures the resonance energy absorbed by hydrogen atoms in the liquid state of the sample; NMR methods give very accurate and precise results. Oil content analysis was done using NMR according to Tiwari et al. (1974).

Statistical analysis: In statistical analysis the data were subjected to analysis of variance (ANOVA). Calculations of ANOVA can be characterized as compu- ting a number of means and variances, dividing two variances and comparing the ratio to a handbook value to determine statistical significance. Calculating a treatment effect is then trivial, "the effect of any treatment is estimated by taking the difference between the mean of the observations which receive the treatment and the general mean. Differences within and between treatments and their significance is best explained in the procedure suggested by Panse and Sukhatme (1984).

A number of statistical procedures are available for analyzing the information gathered from the trials established in different environments. The most widely used method for identifying high yielding and stable genotypes, is the linear regression approach. Eberhart and Russell (1996) used this approach along with deviation from the regression line $\left(\mathrm{S}^{2} \mathrm{di}\right)$ as another stability parameter. In general, the regression models partition the overall response pattern into yield performance and stability. The genotype-environment interaction and stability parameters were estimated as per the model of Eberhart and Russell (1996). A genotype with regression coefficient of unity (bi=1) and the deviation not significantly different from zero $\left(\mathrm{S}^{2} \mathrm{di}=0\right)$ was taken to be stable genotype with high mean response.. The statistical analysis was done with the help of software windostat version 9.1.

\section{RESULTS AND DISCUSSION}

The analysis of variance on 12 characters was carried out individually for each environment as well as pooled over the 5 environments. Analysis of variance revealed significant differences amongst the genotypes for all the observed characters in each of 5 environments. $G \times E$ interaction variance was significant for all the observed characters. Variance due to genotypes and environments was also significant for all the observed characters. These results indicated the presence of substantial amount of genotype $\times$ environment interaction.

Stability analysis was carried out as per Eberhart and

Table 1. List of 30 germplasm accessions.

\begin{tabular}{clllll}
\hline S. No. & Genotype & Source/Pedigree & S. No. & Genotype & Source/Pedigree \\
\hline 1 & Himalini & K2 $\times$ Kangra Local & 16 & Mariena & Exotic collection \\
2 & Janaki & Palampur & 17 & Ariane & Exotic collection \\
3 & Jeewan & Sumit $\times$ LC-216 & 18 & Giza-5 & Exotic collection \\
4 & Surbhi & LC-216 $\times$ LC-185 & 19 & Giza-6 & Exotic collection \\
5 & Him Alsi-1 & K2 $\times$ TLP-1 & 20 & Giza-7 & Exotic collection \\
6 & Binwa & Flak-1 $\times$ SPS 47/7-10-3 & 21 & Giza-8 & Exotic collection \\
7 & Baner & EC-21741 $\times$ LC-214 & 22 & Faking & Exotic collection \\
8 & Bhagsu & RL-50-3 $\times$ Surbhi & 23 & Aoyagi & Exotic collection \\
9 & KL-241 & Giza-7 $\times$ KLS-1 & 24 & Flak-1 & Exotic collection \\
10 & KL-257 & LC-2323 $\times$ KLS-1 & 25 & Canada & Exotic collection \\
11 & KL-263 & KL-223 $\times$ KL-224 & 26 & B-509 & Exotic collection \\
12 & Hearmies & Exotic collection & 27 & Belinka-60 & Exotic collection \\
13 & Nataja & Exotic collection & 28 & Nagarkot & New River $\times$ LC-216 \\
14 & Viking & Exotic collection & 29 & Him Alsi-2 & EC-21741 $\times$ LC-216 \\
15 & Rejeena & Exotic collection & 30 & Himani & DPL-20 $\times$ KLS-1 \\
\hline
\end{tabular}


Devender Sharma and Satish Paul/ J. Appl. \& Nat. Sci. 8 (4): 2040-2048 (2016)

Table 2. List of characters with their units for data recording.

\begin{tabular}{|c|c|c|c|}
\hline $\begin{array}{l}\text { Sr. } \\
\text { No }\end{array}$ & Characters & Units & $\begin{array}{l}\text { Recording of } \\
\text { Observations }\end{array}$ \\
\hline 1 & $\begin{array}{l}\text { Days to } 50 \% \\
\text { flowering }\end{array}$ & $\begin{array}{l}\text { Number of } \\
\text { days }\end{array}$ & Plot basis \\
\hline 2 & $\begin{array}{l}\text { Days to maturi- } \\
\text { ty }\end{array}$ & $\begin{array}{l}\text { Number of } \\
\text { days }\end{array}$ & Plot basis \\
\hline 3 & $\begin{array}{l}\text { Primary } \\
\text { branches/plant }\end{array}$ & Numbers & Five plants \\
\hline 4 & $\begin{array}{l}\text { Secondary } \\
\text { branches/plant }\end{array}$ & Numbers & Five plants \\
\hline 5 & Plant height & $\begin{array}{l}\text { Centime- } \\
\text { tres }\end{array}$ & Five plants \\
\hline 6 & $\begin{array}{l}\text { Aerial bio- } \\
\text { mass/plant }\end{array}$ & Gram & Five plants \\
\hline 7 & Seeds/capsule & Numbers & Five plants \\
\hline 8 & Capsules/plant & Numbers & Five plants \\
\hline 9 & $\begin{array}{l}\text { Seed yield/ } \\
\text { plant }\end{array}$ & Gram & Five plants \\
\hline 10 & Harvest index & Percentage & Five plants \\
\hline 11 & $\begin{array}{l}1000 \text {-seed } \\
\text { weight }\end{array}$ & Gram & Five plants \\
\hline 12 & Oil content & Percentage & Five plants \\
\hline
\end{tabular}

Russell (1966) model for all the observed characters in order to verify presence of variance due to components of $\mathrm{G} \times \mathrm{E}$ interaction (Table 3 ). The genotype $\times$ environment interaction was present and it was highly significant for all the 12 characters studied. Similar finding have been reported by Yadav et al. (2000) and Rai et al. (1989). As the environment selected in the present study were different agro climatic conditions (Palampur, Malan, Kangra and Dhaulakuan), which shows variation in terms of average temperature, humidity and rainfall (Fig 1-3). The presence of significant $\mathrm{G} \times \mathrm{E}$ for the observed characters indicates the relevance of stability analysis.

Environmental index (Ij) directly reflects the poor or rich environment in terms of negative and positive index, respectively. In the present findings (Table 8) mean values over genotypes were generally lower at Palampur (late sowing) location as compared to Dhaulakuan location for the characters, days to 50 per cent flowering, days to maturity, plant height, primary branches per plant, secondary branches per plant, capsules per plant, aerial biomass per plant, seed yield per plant. Similarly, range was wider at Dhaulakuan location in comparison to Palampur (timely sown) location for the above characters and reverse trend in range was observed for 1000-seed weight and oil content percentage. Malan location had wider range value for seeds per capsule and harvest index percentage. The results indicate that the Dhaulakuan location was relatively better suited for the characters, viz., days to 50 per cent flowering, days to maturity, plant height, primary branches per plant, secondary branches per plant, capsules per plant, aerial biomass per plant, seed yield per plant. While, Palampur (timely sown) location was better suited for expression of 1000-seed weight and oil

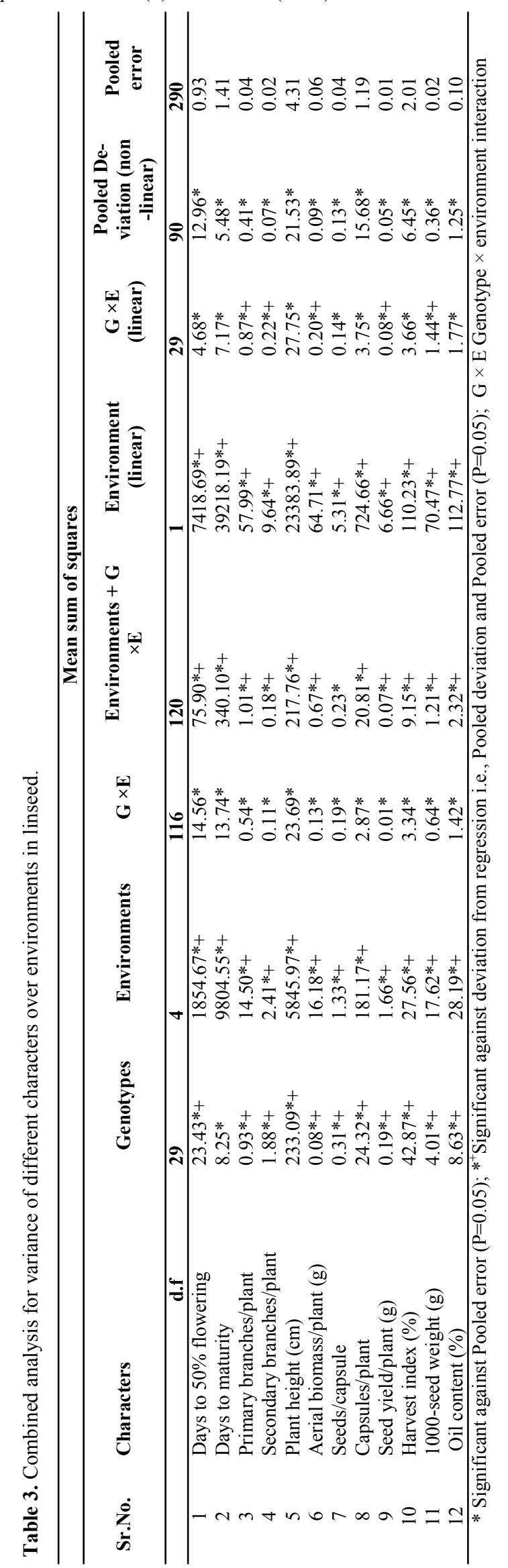


Devender Sharma and Satish Paul / J. Appl. \& Nat. Sci. 8 (4): 2040-2048 (2016)

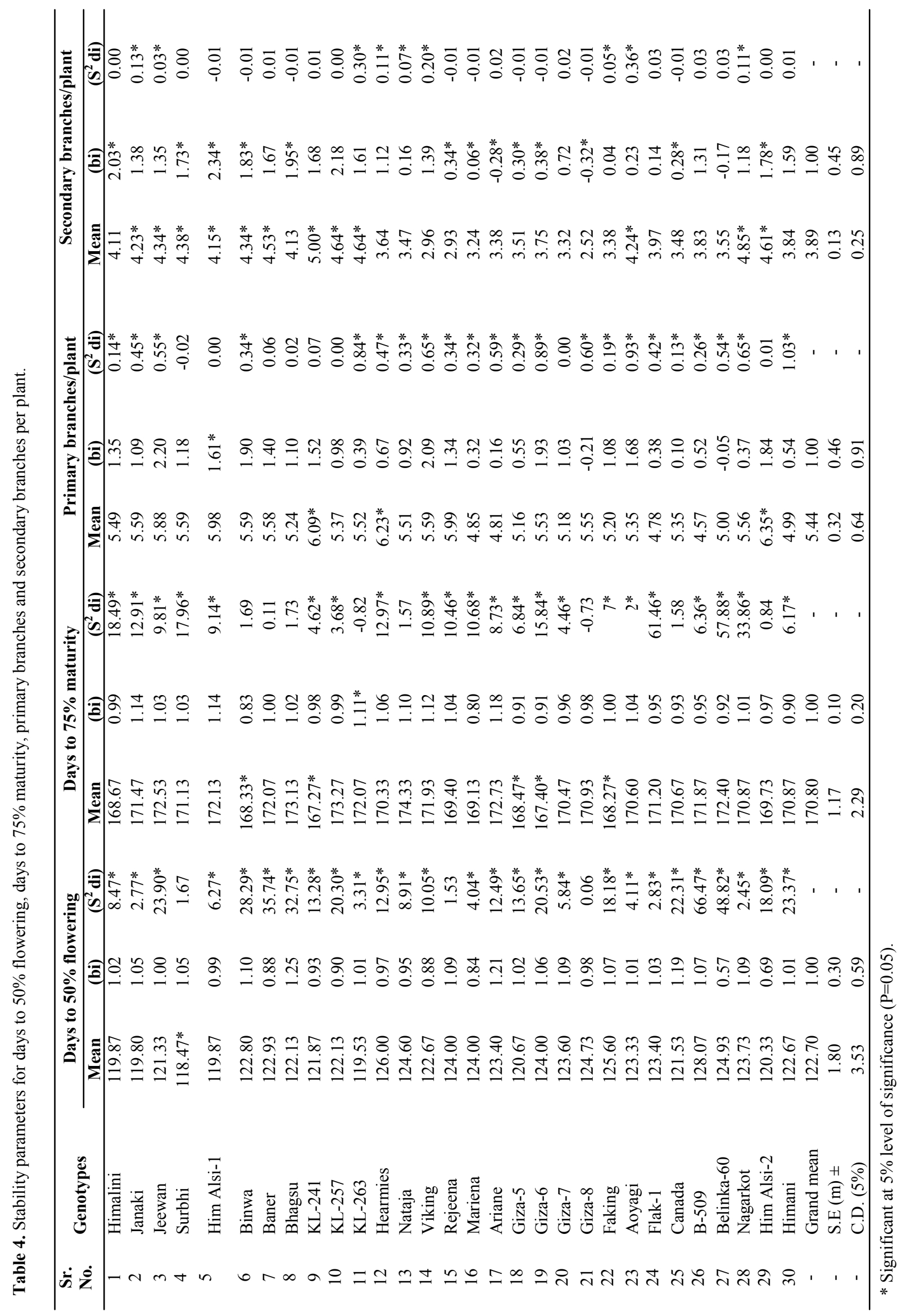


Devender Sharma and Satish Paul / J. Appl. \& Nat. Sci. 8 (4): 2040-2048 (2016)

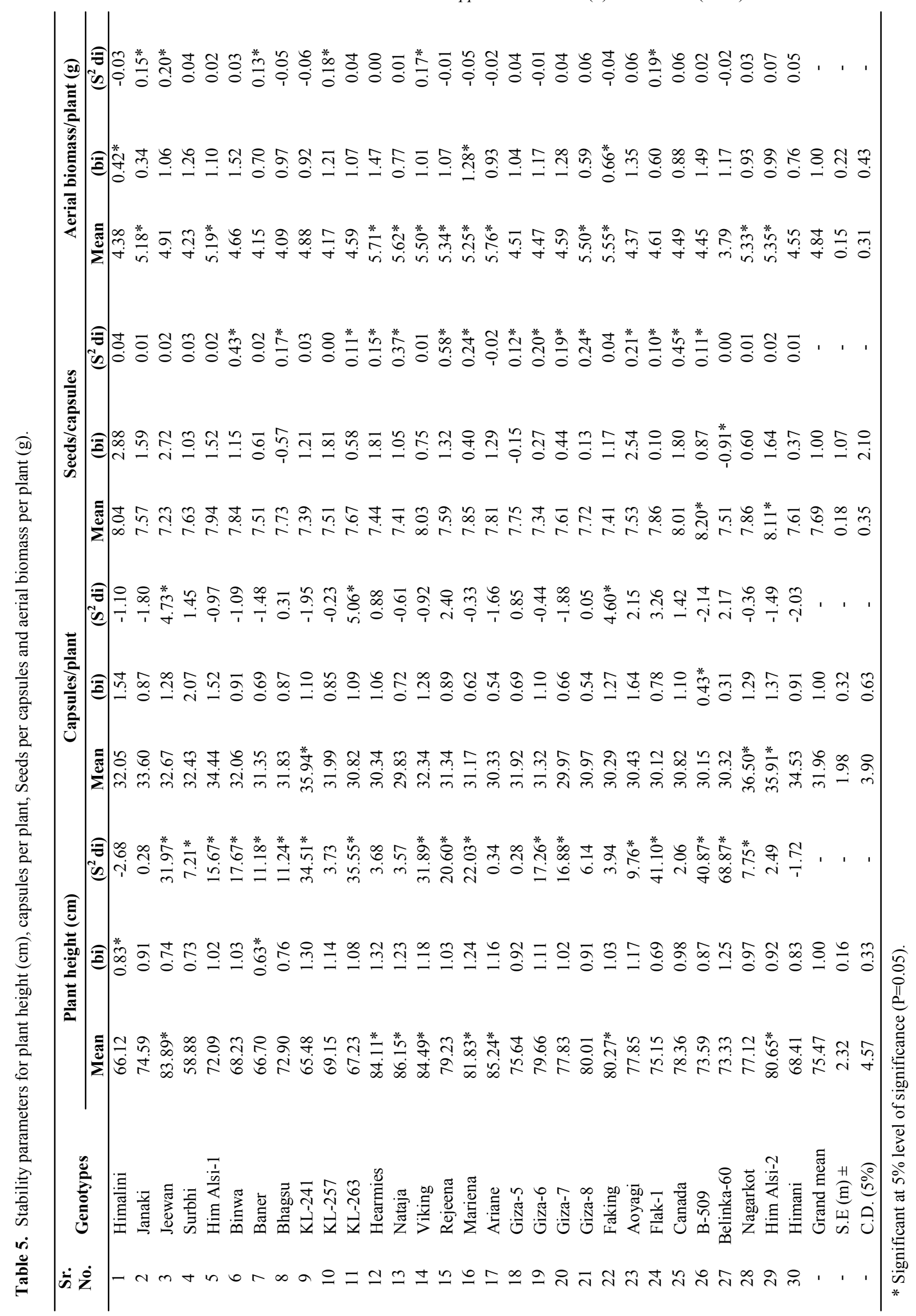


Devender Sharma and Satish Paul / J. Appl. \& Nat. Sci. 8 (4): 2040-2048 (2016)

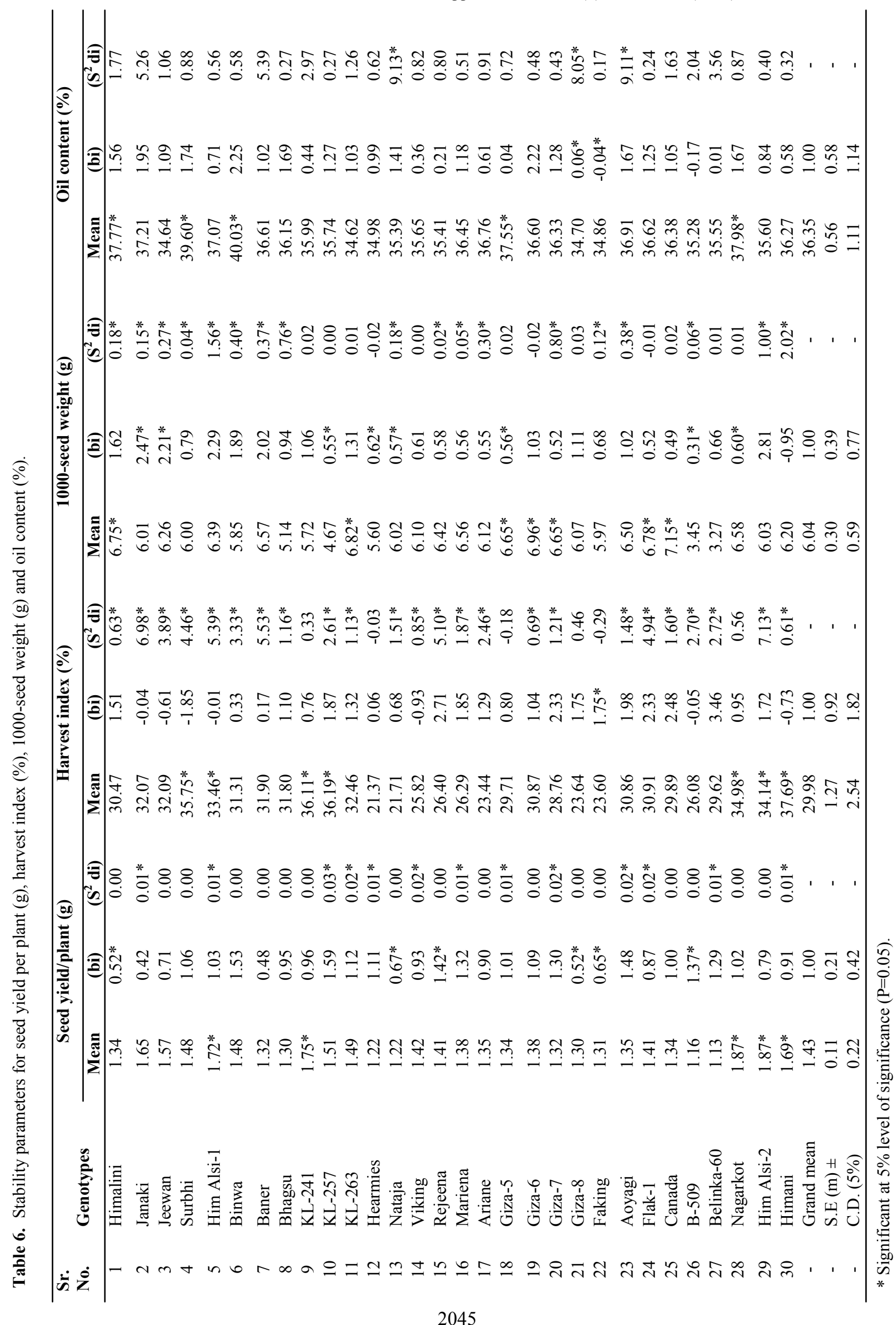




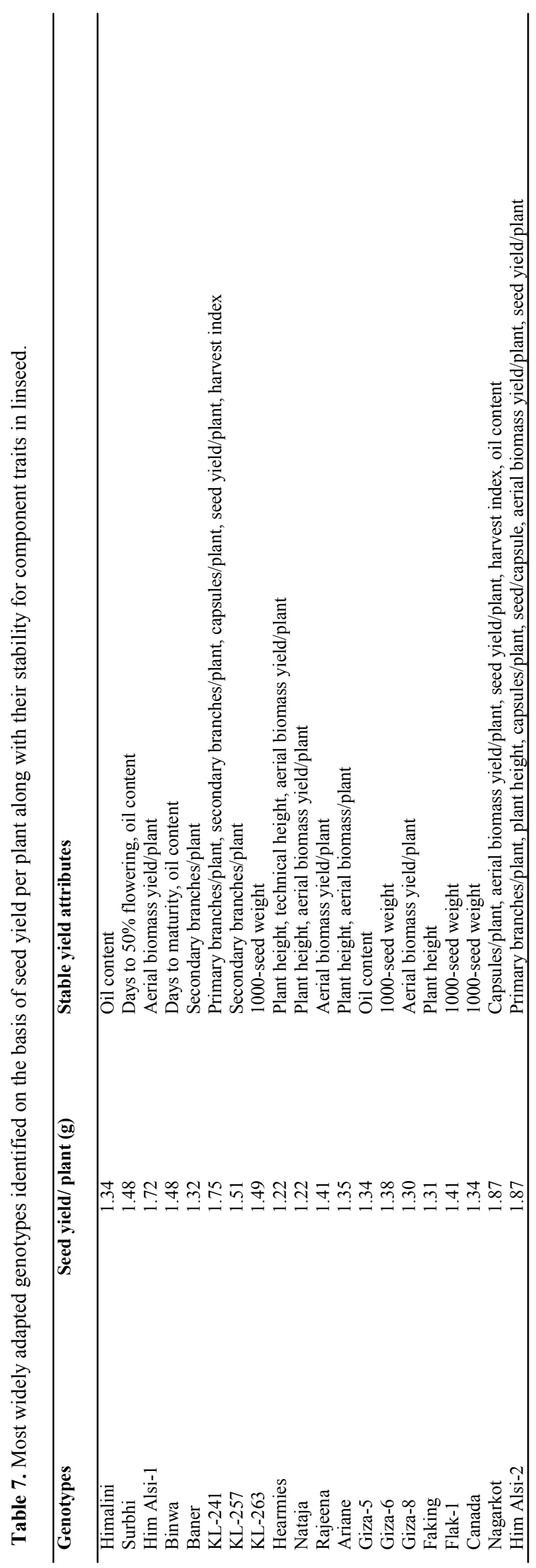

content percentage and Malan location was better suited for seeds per capsule and harvest index percentage.

Analysis of variance for stability indicated significant differences among the genotypes for all 12 characters observed, indicating the diversity in the selected genotypes. Significantly differences was observed among the environments too, hence significant effect of environment was there in the expression of the traits. Genotype $\times$ environment interaction was significant for all the traits studied indicating that the genotypes are varying over the environments due to $\mathrm{G} \times \mathrm{E}$. The significant $G \times E$ interaction has been reported for various traits by Mishra and Rai (1993) and Yadav et al. (2014), which confirm the finding of present investigation. $\mathrm{G} \times \mathrm{E}$ (linear) is also significant for 5 traits viz., primary branches per plant, secondary branches per plant, aerial biomass per plant, seed yield per plant and 1000 -seed weight show substantial amount of predictable $\mathrm{G} \times \mathrm{E}$ interaction. Hence, we can predict the performance of genotypes over wide range of environments for these traits. Significant $G \times E$ (linear) for different traits has been reported by Yadav et al. (2014); Vishnuvardhan and Rao (2014).

All the 12 traits were having high significant pooled deviation which indicated that entire amount of $\mathrm{G} \times \mathrm{E}$ was unpredictable. Significant deviation from regression has been reported earlier also by Yadav and Ram Krishna (2000). $(\mathrm{G} \times \mathrm{E})+\mathrm{E}$ component was not significant for seeds per capsule. However, in the present study genotypes were tested for 3 parameters of stability for all the observed characters.

The stability parameters of 30 genotypes for 12 traits have been given in the Table (4-6). According to Eberhart and Russell (1966) a stable genotype is one which shows (i) a high mean yield (ii) a regression coefficient equal to unity (bi=1), and (iii) a mean square deviation from regression equal to zero $\left(S^{2} \mathrm{di}\right)$. The linear regression (bi) is treated as a measure of response of a particular genotype, whereas deviation from the regression line $\left(\mathrm{S}^{2} \mathrm{di}\right)$ is considered as a measure of stability. Accordingly, the genotypes with least or non significant deviation are regarded as most stable and vice-versa. Out of 30 genotypes, the genotypes KL -241, Him Alsi-2 and Nagarkot were identified to be high yielding and stable genotypes as they possess high mean performance with unit regression and non linear deviation from regression. Thus, these 3 genotypes were suitable for all the 5 environments viz., Palampur (timely and late sown), Malan, Kangra and Dhaulakuan of different agro climatic situation of Himachal Pradesh. Stability of the genotypes for various traits on the basis of 3 parameters has earlier been reported by Yadav et al. (2000), Vishnuvardhan and Rao (2014) which confirm the present findings where various genotypes are showing stability for 1 or more characters. Genotype KL-241 besides having stable and high performance for seed yield per plant (g), also having supe- 
Table 8. Mean performance over environments and estimates of environmental indices in different environments as deviation from grand mean.

\begin{tabular}{|c|c|c|c|c|c|c|c|c|}
\hline \multirow[t]{2}{*}{ Character } & \multirow{2}{*}{\multicolumn{3}{|c|}{ Mean \pm S.E.(m) }} & \multicolumn{5}{|c|}{ Environment } \\
\hline & & & & $\mathbf{E}_{1}$ & $\mathbf{E}_{2}$ & $\mathbf{E}_{3}$ & $\mathbf{E}_{4}$ & $\mathbf{E}_{\mathbf{5}}$ \\
\hline Days to $50 \%$ flowering & 122.70 & \pm & 1.80 & 3.03 & 11.76 & -0.96 & -5.60 & -8.22 \\
\hline Days to maturity & 170.80 & \pm & 1.17 & 16.43 & 14.98 & 4.82 & -9.96 & -26.28 \\
\hline Primary branches/plant & 5.44 & \pm & 0.32 & -0.05 & -0.91 & -0.33 & 0.38 & 0.92 \\
\hline Secondary branches/plant & 3.89 & \pm & 0.13 & 0.06 & -0.47 & -0.01 & 0.13 & 0.29 \\
\hline Plant height $(\mathrm{cm})$ & 75.47 & \pm & 2.32 & 6.10 & -23.05 & 1.32 & 1.20 & 14.42 \\
\hline Aerial biomass/plant (g) & 4.84 & \pm & 0.15 & 0.03 & -1.15 & 0.30 & -0.04 & 0.86 \\
\hline Seeds/capsules & 7.69 & \pm & 0.18 & -0.06 & -0.14 & 0.30 & -0.23 & 0.13 \\
\hline Capsules/plant & 31.96 & \pm & 1.98 & -1.09 & -2.69 & 1.56 & -1.22 & 3.44 \\
\hline Seed yield/plant (g) & 1.43 & \pm & 0.11 & 0.02 & -0.39 & 0.14 & 0.01 & 0.22 \\
\hline Harvest index (\%) & 29.98 & \pm & 1.27 & 0.04 & -1.05 & 0.84 & 1.04 & -0.87 \\
\hline 1000-seed weight $(\mathrm{g})$ & 6.04 & \pm & 0.30 & 1.18 & 0.05 & 0.14 & -0.61 & -0.75 \\
\hline Oil content $(\%)^{*}$ & 36.35 & \pm & 0.56 & 1.72 & -0.53 & -0.55 & -0.41 & -0.23 \\
\hline
\end{tabular}

$\mathbf{E}_{1}$ : Palampur-I (1 $1^{\text {st }}$ sowing); $\mathbf{E}_{2}$ : Palampur-II ( $2^{\text {nd }}$ sowing); $\mathbf{E}_{3}$ :Malan; $\mathbf{E}_{\mathbf{4}}$ : Kangra; $\mathbf{E}_{5}$ : Dhaulakuan.

Temperature variation $\left({ }^{\circ} \mathrm{C}\right)$

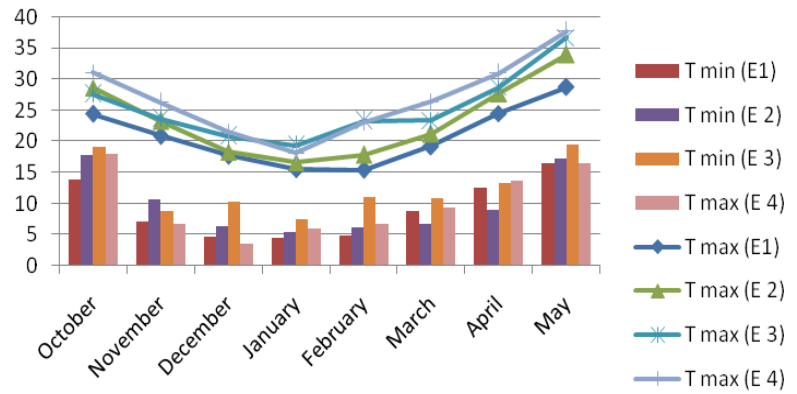

Fig. 1.

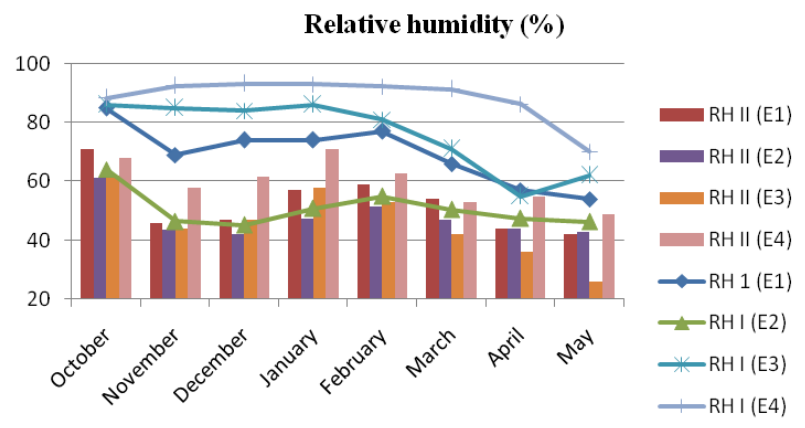

Fig.2.

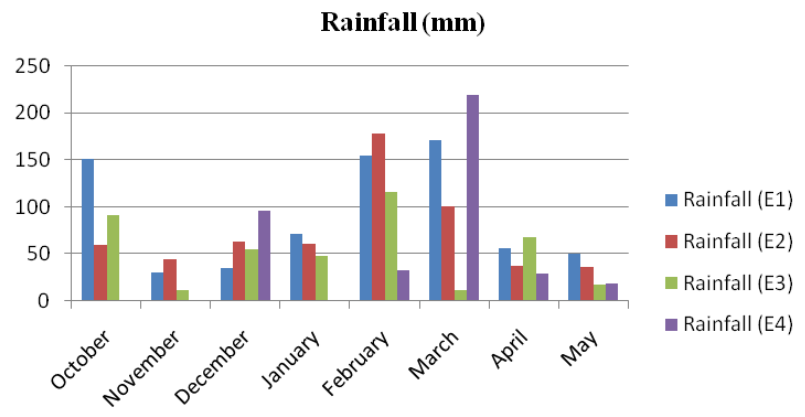

Fig.3.

Fig. (1-3). Environmental (Temperature, relative humidity and rainfall) variations across the locations. rior performance for primary branches per plant, secondary branches per plant, capsules per plant and harvest index. Likewise, Nagarkot having stable and superior performance for capsules per plant, aerial biomass yield per plant $(\mathrm{g})$, straw yield per plant $(\mathrm{g})$, harvest index and oil content in addition to seed yield per plant (g). Genotype Him Alsi-2 also had stable and high performance for primary branches per plant, plant height, capsules per plant, seeds per capsule, aerial biomass yield per plant $(\mathrm{g})$ along with seed yield per plant $(\mathrm{g})$. These genotypes identified on the basis of seed yield per plant were also stable for other yield contributing traits (Table 7) and could be utilized for all the environments to achieve higher and stable yield. Yadav et al. (2014) had also concluded from their study in linseed that stability for seed yield is associated with stability for yield components viz; numbers of capsules per plant, numbers of seeds per capsule and 1000 -seed weight.

Giza-5 had low deviation from linearity $\left(\mathrm{S}^{2} \mathrm{di}\right)$ but regression coefficient less than unity for 1000-seed weight, therefore suitable for poor environmental conditions and least sensitive to environmental conditions. In favourable environment the performance of such genotype may fail to respond even moderately. Surbhi, Him Alsi-1, Him Alsi-2 and Binwa for secondary branches per plant and genotype Mariena for aerial biomass yield per plant $(\mathrm{g})$, showed the regression coefficient $>1$ with low deviation from linearity $\left(S^{2} \mathrm{di}\right)$. Hence these genotypes are suitable for rich environmental conditions with respect to these traits. Under the poor environments may not perform better.

\section{Conclusion}

In conclusion, this study showed the presence and the type of GE interactions among the 30 linseed genotypes and their yield components. High-yielding genotypes with broad adaptation and some genotypes with specific adaptation were identified. Three genotypes, viz., KL-241, HimAlsi-2 and Nagarkot should be included in any breeding programme where objective is 
really to develop high yielding stable genotypes over environments. Moreover, based on the results of present study it is revealed that in segregating generation of such crosses including these parents, direct selection for 1000-seed weight, number of tillers/plant along with simultaneous selection for number of branches/ plant, number of capsules/plant will be responsive for improvement of seed yield/plant. The genotypes stable over environments can be used successfully for developing stable strains having wider adaptability in the future breeding programme.

\section{REFERENCES}

Anonymous (2014). Annual report 2013-14 linseed. AICRP (All India Coordinated Research Project) on linseed. Kanpur, India.

Arora, S., Modgil, R., Sood, S. and Bhateria, S. (2003). Physio-chemical and nutritional qualities of different cultivars of linseed (Linum usitatissimum L.). J. Food. Sci. Tech., 40: 324-327

Compbell, H.G. and Lafever, H.N. (1977). Cultivar x environment interaction in soft and red winter wheat yield tests. Crop Sci., 17: 604-608

Eberhart, S.A. and Russell, W.A. (1966). Stability parameters for comparing genotypes. Crop Sci., 6: 36-40

Fernald, M.L. (1950). Gray's manual of botany. Eighth edition (Corrected Printing, RC Rollins 1970), De Van Nostrand Company, New York, pp 1632

Gill, K.S. (1987). Linseed, ICAR Publication, New Delhi, India.
Khan, M.L., Sharif, M. and Sarwar, M. (2010). Chemical composition of different varieties of linseed. Pak. Vet. $J ., 30$ (2): 79-82

Mishra, V.K. and Rai, M. (1993). Stability analysis for seed yield, components of seed and oil in linseed (Linum usitatissimum L.). Indian J. Genet., 53: 165-167

Panse, V.G. and Sukhatme, P.V. (1984). Statistical methods for agricultural workers. Indian Council of Agricultural Research, New Delhi. p 359

Rai, M., Kerkhi, S.A., Pandey, S., Naqvi, P.A. and Vashistha, A.K. (1989). Stability analysis for some quality components of seed and oil in linseed (Linum usitatissimum L.). Indian J. Genet., 49: 291-295

Tiwari, N.P., Gambhir, N.P. and Rajan, S.T. (1974). Rapid and no destructive determination of seed oil by pulsed Nuclear Magnetic Resonance Technique. J. Am. Oil Chem. Soc., 51: $104-109$

Vishnuvardhan, K.M. and Rao, S.S. (2014). Stability analysis for yield and its attributing characters in linseed (Linum usitatissimum L.). Int. J. Pl. An. and Env. Sci., 4: 408-412

Yadav, R.K. and Krishna, R. (2000). Stability analysis for some quality traits in linseed. Indian J. Agr. Biochem., 13: $50-51$

Yadav, R.K., Singh, P.K. and Gupta, R.K. (2000). Phenotypic stability for yield and quality attributed in linseed (Linum usitatissimum L.). Crop. Res., 19: 301-304

Yadav, R.K., Yadav, A.K., Shweta, S., Singh, L. and Verma, P.N. (2014). Stability analysis in linseed (Linum usitatissimum L.) varieties. Indian Agr. Sci., 84: 883-886 